\title{
Effect of Reinforcing Factors (Role of Parents and Role of Teachers) in Prevention of Dental Caries in Children
}

\author{
Masyitah $^{1}$, Ida Yustina ${ }^{2}$, Etti Sudaryati ${ }^{2}$ \\ ${ }^{1}$ Master Student in Universitas Sumatera Utara, Medan, Indonesia \\ ${ }^{2}$ Lecturer in Universitas Sumatera Utara, Medan, Indonesia \\ Email: masyitahlubis71@gmail.com
}

\begin{abstract}
:
The aims on the study is to find out reinforcing factors in prevention of dental caries in children. This type of research is an observational analytic study with a cross sectional approach. The result of this study it can be concluded that there is an influence of the reinforcing factors which include: there is an influence of the role of parents on the prevention of dental caries in children with a value of $p=0.001$ and there is an influence of the role of the teacher on the prevention of dental caries in children in elementary school Pantai Labu District with a value of $p=0.001$. The dominant factor influencing the prevention of dental caries in children in elementary school in Pantai Labu District is the role of parents with a value of $p=0.001$ (Exp B 8.825).

Keywords:

effect of reinforcing factors; prevention; dental caries
\end{abstract}

\section{Introduction}

Damage to the tooth structure that is often suffered by children due to infectious diseases is called dental caries. Microorganisms, host, substrate/diet and time are factors that have a relationship in the process of dental caries occurring in the mouth which is the main factor. Besides the main factors there are external factors as predisposing factors including: age, sex, socioeconomic, oral hygiene, and cryogenic food (Khotimah, et. al., 2014). The behavior of cleaning the mouth in elementary school children is one of the supporting factors (predisposing factors) that are very instrumental in the occurrence of dental caries. This can be due to lack of information about how teeth are brushed properly, so that children carelessly brush their teeth (Jannah, et. al., 2016).

The basic microbiological model that explains caries development has been replaced by a broader model, which also includes socioeconomic, demographic and behavioral factors, such as ethnicity and family income, as well as parental education and knowledge, dietary patterns, cultural and technological factors (Do \& Spencer, 2015; Moima, et al., 2016). Many factors at the individual level that contribute to dental caries in children include brushing frequency and duration of tooth brushing (Argawal, et. al., 2014). The prevalence of caries and its severity cannot be determined by considering only one factor. All factors must be considered as a whole for health promotion so that it can help promote the prevention and treatment of dental caries (Jain, et. al., 2015).

Caries in children affects the quality of life of children and their families (Martins, et. al., 2015). Dental caries can affect a child's eating because the child will have difficulty chewing, moving, social interaction, absence from school, quality of sleep, smiling, talking, socializing, playing, psychological problems and general health problems (Clementino, et. al., 2015). In addition, dental caries affects children's growth and well-being, and when this activity is disrupted, will affect the quality of life of children (Gaur \& Nayak, 2011; Martins, et. al., 2015). 
Hollins research (2012) in Canada, regarding the condition of children before dental caries are treated, shows children have dental pain complaints as much as 48 percent, children have problems eating certain types of food as much as 43 percent, children do not spend 61 percent of their food, children do not have good sleep quality by as much as 35 percent and reports from schools that are not good as much as five percent, such as lack of cooperation and reluctance to play with friends. Sleep quality of children is disturbed due to pain arising from dental caries (Windarti, 2018).

Dental caries is a chronic multifactorial condition, prevention that requires the implementation of effective measures at different levels. Understanding factors in the community, school, family and individual are important to ensure appropriate preventive measures and treatment for children (Cadavid, et. Al., 2010).

Despite the reduction in tooth decay in pediatric populations in all countries, dental caries remains the most common childhood disease (Clementino, et. Al., 2015). Caries in children is a chronic infectious disease, which is difficult to control. Although not life threatening, the impact on individuals and society is to consider the cost of treatment, cause pain, impaired function, affect the child's growth rate, weight, and ability to develop, thereby reducing quality of life (Jain, 2015).

The high level of dental caries severity, the prevalence and the still low motivation in children to treat their teeth is due to several factors, among others, knowledge, attitude and behavior factors (actions). Riskesdas 2018 data, there were 57.6 percent of the proportion of dental and oral health problems, of which 93 percent were the proportion of dental caries in early childhood, 10.2 percent received service efforts from dental medical personnel, 2.8 percent proportion of teeth brushing behavior by correct (after breakfast and before going to bed at night) (Ministry of Health, 2018).

\section{Review of Literature}

\subsection{Dental Caries}

Dental caries can be interpreted as a disease that occurs in hard tooth tissue, such as enamel, dentin and cementum, which begins with the gradual destruction of dental minerals on the tooth surface ie pit, fissure, and interproximal areas and then spread to the pulp, resulting in infected areas in the teeth. This process occurs because of the fermentation of microorganism activity in carbohydrates. This causes bacterial infiltration and damage to pulp tissue and spread of infection to the periapical tissues, causing pain in the teeth (Tarigan, 2014; Pintauli \& Hamada, 2015).

Dental caries is caused by bacteria where the sucrose fermentation results are used in gluing bacterial cells on the surface of tooth enamel. These bacteria colonize each other and form aggregates in dental plaque (Sari, Ulfiana \& Rachmawati, 2019).

Symptoms of dental caries. Dental caries problems have symptoms such as toothaches, teeth feel uncomfortable after drinking and consuming foods that are acidic, cold, hot, and sweet like the teeth feel achy, look and feel holes in the teeth and the appearance of unpleasant odor (halitosis) (Cardoso, et al., 2015).

Signs of dental caries. According to Tarigan (2014), the process of dental caries is characterized by: (1) The appearance of white spots / white spots on tooth enamel (visible 
areas of demineralization due to acid); (2) Discoloration in tooth enamel to brown, until holes are formed (tooth decay); (3) If the dentin has been damaged, will cause complaints of pain or pain, after eating or drinking; (4) If tooth decay has reached the pulp causing complaints of pain that is felt, not only after eating, but occurs continuously which has the effect of disrupting daily activities.

G.V Black has categorized cavities into six locations, which are marked by numbering using roman numerals, based on the surface of the teeth that have been affected by caries, namely:

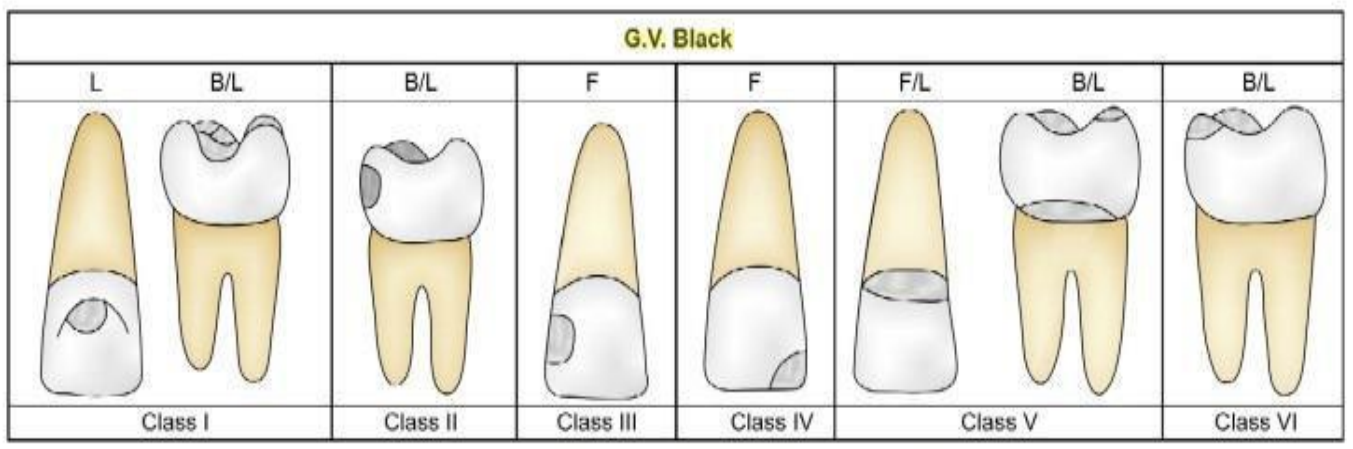

Figure 1. Categories of caries according to G.V. Black

Source: Caries Gigi Tarigan, 2014

\subsection{Factors that Influence the Prevention of Dental Caries in Children}

Factors that influence the application of caries prevention in children's teeth according to L. Green's theory in McKenzie \& Smeltzer (1997) divide two health problems namely behavioral factors and non-behavioral factors. L. Green states that behavioral factors are determined by three factors:

Predisposing factors (predisposing factors). These factors include children's knowledge and attitude towards dental caries prevention behavior so that it becomes an antecedent of the behavior that is the basis or motivation for their actions due to habits, beliefs, socioeconomic and educational levels, such as knowledge, attitude, beliefs and values of a child in prevent teeth not caries (hollow).

Supporting factors (enabling factor). This factor is an antecedent of behavior that allows a motivation or action to be carried out. This factor covers the availability of infrastructure and health facilities for school children, namely the UKGS room, clean water, a place for children to rinse (water faucets), the availability of toothpaste containing flour, toothbrushes, fluoride application, and healthy canteen. This facility basically supports the occurrence of dental caries prevention behavior in school children.

Push factors (reinforcing factors). This factor is a factor that states whether or not there is support from health measures. This factor is seen in the form of attitude and behavior of parents and teachers who are figures that are obeyed or trusted by children such as parents giving the example by brushing their teeth twice a day, and always rinse their mouth or brush their teeth immediately after consuming sweet foods. The teacher always teaches children proper brushing and motivating techniques so that children always maintain oral health. This is as a reinforcement in the behavior of dental caries prevention in elementary school children.

The role of parents in the prevention of dental caries in primary school children. Role 
is a person's ability to monitor, influence or change the behavior of others. Mother and biological father are called parents, bound in a marriage and are willing to assume the responsibilities of the children born. Parents are the first to teach knowledge to children and are responsible for their growth process. The role of the environment and the role of parents also influence children's development. Every activity caring for and caring for children in order to grow and develop children to run optimally needs to apply the pattern of compassion, fostering and sharpening to children (Papalia, et. al., 2008).

Parents are role models for children, parents' behavior and habits in the family environment are expected to be a good role model for children. Like the habit of brushing teeth properly and regularly it is expected to be able to be imitated by children who have not entered school.

The role of parents in trying to prevent dental caries in children. The role of parents is: (1) Supervise when a child brushes his teeth and helps him to clean his teeth, especially if the child is under the age of five; (2) Notifying children and watching the right time to brush their teeth, after breakfast and at night before going to bed, this is done to form permanent good habits to children; (3) Preparing toothpaste and toothbrushes; (4) Periodically check teeth in children to the dentist's practice; (5) Monitoring the types of snacks chosen by children; (6) periodically sending children to health care facilities to check and care for teeth and mouth; (7) Examining their children's teeth to see whether there is cavity or tartar (Hutabarat, 2009; Husna, 2016).

Regarding behavior, factors that can affect the health status of the community are inseparable from the culture and habits of the family and the daily environment of the community according Notoatmojo in Ismail Fahmi (2019). Cultural values are concepts about something that is in the mind of most of the people they consider valuable, valuable, and important in life so that it can function as a guide that gives direction and orientation to the lives of the citizens according Koentjaraningrat in Ismail Fahmi 2019.

\section{Research Method}

This type of research is an observational analytic study with a cross sectional approach, which is the type of research conducted at the time of measurement or observation to collect data at a particular time which is carried out on independent variables and dependent variables to describe the condition of the population (Sugiono, 2016).

This research will be conducted in elementary schools (SD) in Pantai Labu Subdistrict of Deli Serdang Regency with the number of primary schools of 24 . The selection of research sites is carried out by simple random sampling, mixing subjects without considering levels in the population because they are considered homogeneous. Populations greater than 100 then use the 10-15 percent requirement (Arikunto, 2003). The calculation is $24 \mathrm{SD} \times 10$ percent $=$ 2.4 , then it is completed into three elementary schools, then we revoke the lottery numbers, until three numbers are fulfilled, the selected elementary schools are SDN 104255, SDN 101928, and SDN Ramunia I. When the research was conducted starting in May 2019 until February 2020. 


\section{Discussion}

The prevention of dental caries in children in primary school is also influenced by reinforcing factors. This factor encourages or inhibits changes in health behavior. These reinforcing factors include: the role of parents and the role of teachers.

The influence of the role of parents on the prevention of dental caries in primary school children. Statistically shows there is an influence of the role of parents on the prevention of dental caries in children with a value of $\mathrm{p}=0.001$. This situation explains that there is a tendency for children whose parents have a good role to take action to prevent dental caries. The results of this study are in line with Hsieh, Huang, Tsai, and Hsiao (2012) stating that the role of the best parent is to provide examples of concrete actions. Parents who brush their teeth twice a day affect their habits of brushing their teeth and children tend to do the same thing than parents who do not do it.

The role of parents is a factor in line with the results of Arianto's research (2013), has an influence on children's actions to maintain healthy teeth by brushing their teeth $(p=0.008)$. Children who have tooth brushing behavior, most of the roles of their parents are good $(51.6 \%)$, which is described as having a concern for the provision of toothbrushes as desired. Dental hygiene is something that must be maintained with routine action, and parents who are well educated, understand that the characteristics of toothbrushes, are one of the encouragement for children to practice without feeling burdened. The desired toothbrush is mostly small, straight-handled and soft-brained. The role of parents is mostly lacking (54\%) does not fulfill the things the child wants to brush their teeth. Parents who are able to play the role will be able to increase the likelihood of children taking action to brush their teeth.

Parents in this study generally have not performed their role well in reminding children to brush their teeth. School-age children still need to be reminded about the time to brush their teeth, especially when going to sleep. The mother who always reminded, over time will form the habit because behavior changes require a long time. Mothers not doing their role can be caused by forgetting because they have busy taking care of the household every day. Domestic work that drains all physical endurance and can be a higher burden on mothers who have children under five. School-age children are considered to be old enough to take care of themselves, so sometimes mothers focus more on younger children.

Other obstacles can come from the children themselves who think that brushing their teeth is not fun so it requires a lot of time to encourage children to be willing to do it. Children generally prefer to be accompanied by mothers when brushing their teeth and taught the right way, but in this study mothers only accompanied while doing other activities. Mothers who are not focused and let their children brush their own teeth will have different results on mothers who involve themselves.

The role of parents is very necessary in guiding, providing understanding, reminding, and providing facilities to children so that children can maintain oral and dental hygiene. Parents have a very big role in preventing plaque accumulation and dental caries. There is a significant relationship between the role of parents and children's behavior in brushing their teeth with the caries incidence of children aged 5-6 years at Sekar Melati kindegarden Village Pal IX, Sei Kakap sub-district, Kubu Raya Regency (Husna, 2016).

The impact of the role of parents in the prevention of dental caries in children is significant, in line with Clarke (2017), which is seen from the prevalence of low dental caries 
on the role of good parents. The aspect that requires parental involvement mainly gives confidence to the child that the precautions taken will provide tangible results as informed. Strengthening given by parents will provide great encouragement to children to adhere to care for oral health. Parents have a great influence on children's willingness to adopt healthy behaviors, and are the main source of information that children trust. Parents who play an active role such as making various efforts so that children brush their teeth twice a day will reduce the risk of children experiencing dental caries while parents who can control children to limit the intake of foods harmful to dental health will prevent children from suffering from dental caries.

Another role of parents that needs to be improved in this research is to encourage children to introduce children to the need for a check-up with health workers, both in the condition of healthy or sick teeth. Mothers have to get rid of the longstanding picture that visiting a health center or dentist is a scary thing and is only done when the tooth has been sick. In line with Garcia (2016) who said that parents have an important role in the prevention of dental caries. This role is done by parents by informing children of the urgency of visiting a dentist. The next visit to the health professional will get various personal information that must be done to maintain dental health in order to avoid caries.

Tooth brushing behavior, diet, dental care and regular visits to the dentist will affect the good and bad health of the teeth and mouth, which will affect the dental caries score (Andriyani, 2014). Plaque is one indicator of dental care by brushing is not done with a frequency of at least twice a day. This is in line with Wirodona, et. al., (2013), that the role of parents is something important to encourage children to brush their teeth regularly. The role of parents is good, most children $(40.5 \%$ ) have lower plaque scores (reflecting the growth of plaque thickness on the tooth surface), whereas in the role of parents less, the plaque score is higher $(63.7 \%)$.

Another role that parents have not done well is the selection of snacks. Parents have not given the right limits about sweet foods. Eating sugary foods is one part of preventing dental caries. Mother still allows children to eat bread and snacks that contain high sugar. This can be due to mother's inadequate knowledge about the mechanism of dental caries so that it does not carry out strict supervision and forbid children to consume this type of food. Parents can assume that brushing their teeth is the most important thing to do while maintaining food is not yet known among parents. Parents have not tried to equip children with foods that are low in sugar. Sweet food left in the mouth has not been seen as a danger that can threaten dental health.

Dental caries is the most common problem experienced by children and parents as one that plays a role in preventing the incident, generally has a low contribution. This is in line with Arora, Manohar, and John (2017), the examination conducted on school-age children showed that the majority $(50.6 \%$ ) had dental caries and most of it was found in 60.4 percent of mothers and 58.9 percent of fathers who have a history of poor dental health. Parents who do not contribute to making children take care of their dental health properly, starting from the limitation of consumption of sweet foods, it is known that most have children with dental caries. Caries children consume chocolate and sugary drinks per day higher than children without dental caries. Mothers who do not play a good role in encouraging children to take care of teeth have the potential to cause children to experience dental problems. 
The effect of the teacher's role on the prevention of dental caries in children in primary school. Statistically shows there is an influence of the teacher's role on the prevention of dental caries in children with a value of $p=0.001$. This situation explains that there is a tendency for children who have a teacher with a good role in efforts to prevent dental caries to take good dental caries prevention measures. The results of this study are in line with Blake, Dawett, Leighton, and Rose-Brady (2014) that precautionary measures against dental caries tend to be applied along with the addition of children's insight about oral hygiene, the mechanism of cavities, and foods that can cause cavities, and the benefits of brushing teeth. Children's knowledge is easier to increase in teachers who want to be involved in dental health programs in schools.

The role of the teacher is important in encouraging children to cultivate oral health habits by brushing their teeth properly. Tooth brushing behavior includes preventive measures in preventing oral and dental diseases (Andriyani, 2014). Teachers who have a good role according to Arianto (2013) have the opportunity to encourage children to take dental care measures to prevent dental caries higher than parents, which is almost eight times.

This research generally explains that the encouragement of teachers to hold regular tooth brushing activities has never been done. This can be because the teacher feels that he is giving information to the child about how to brush their teeth properly, counseling about maintaining dental health, checking the child's dental health, and informing that food should be limited enough to encourage children to take the same actions at home. Teachers with their busy schedule do not realize that brushing behavior must be encouraged continuously. Mass teeth brushing is an exciting activity besides being an activity to inform all matters related to maintaining dental health.

In line with Maranhão, de Araújo, Vieira, and Costa (2013), the teacher's role is an urgent utility that he must have so that a child avoids dental caries by implementing preventive measures against the problem. The role of the teacher in the prevention of dental caries will be optimally carried out in teachers with good knowledge and attitude. The assumption that sugar is the cause of dental caries is an example of the inaccuracy of knowledge possessed by the teacher, and a small portion $(3.6 \%)$ gives a correct statement that the frequency of sugar consumption is the main cause. The total number of teachers, who knew that plaque was the cause of dental and gum problems, did not differ much at lower levels (32.1\%). More specifically it was found that the teacher's predicted knowledge would influence his role in dental care issues, higher in mothers who had children.

Dental health programs in schools will be successful if there is a high involvement of teachers in it. Research conducted by Dania and Adebayo (2019) found that school-age children would take action to maintain dental health more applicable with information provided by teachers. The right information will be able to be given by teachers with good knowledge about the programs run by the government. The great role of the teacher in persuading students to do good things that are required in maintaining healthy teeth, can not be fully utilized by competent people. The teacher in part on this research in Nigeria, was found to be still relatively low in knowledge. Dental health programs in schools are not fully understood so that the delivery of information to students is not able to achieve the expected goals, namely the transfer of knowledge with the long-term goal of improving the quality of student life. 
Teachers can provide information interactively to deal with children who have not done proper dental prevention, including involving parents. The information provided in the usual way can be tedious and look like a formal activity so the impact produced is also not as expected. Children tend to be more easily encouraged by providing information that uses characters they already know or uses things that are more interesting and increases their involvement. Children who get information passively are less involved with the recommended action. Eley, et. al., (2018) said that interactive programs designed using cyberspace were proven to have helped teachers to encourage children to adopt behaviors to maintain dental health. Healthy behavior especially maintaining dental health must be done from a young age, and interactive programs designed to involve teachers are known to have a very real impact on changes in children's behavior.

Baltaci, Baygin, Tuzuner, and Korkmaz (2019) said that the teacher is the person who interacts most often with children after parents so that building the right behavior related to oral health become one of its roles. The impact of information and education provided by teachers is known to be more effective than parents. This causes teachers to have a better level of knowledge about dental health including awareness of providing more information to children. Teachers are encouraged to receive training so that they can improve on the topics to be addressed to children including allocating more activities related to oral health maintenance, including the prevention of dental caries.

\section{Conclusion}

From this study it can be concluded that there is an influence of the reinforcing factors which include: there is an influence of the role of parents on the prevention of dental caries in children with a value of $\mathrm{p}=0.001$ and there is an influence of the role of the teacher on the prevention of dental caries in children in elementary school Pantai Labu District with a value of $\mathrm{p}=0.001$. The dominant factor influencing the prevention of dental caries in children in elementary school in Pantai Labu District is the role of parents with a value of $\mathrm{p}=0.001$ (Exp B 8.825).

\section{References}

Abanto, J., Vidigal, E. A., Carvalho, T. S., \& BÖNECKER, M. (2017). Factors for determining dental anxiety in preschool children with severe dental caries. Braqiilian oral research, 31.

Afiati, R., Adhani, R., Ramadhani, K., \& Diana, S. (2017). Hubungan perilaku ibu tentang pemeliharaan kesehatan gigi dan mulut terhadap status karies gigi anak tinjauan berdasarkan pengetahuan, tingkat pendidikan, dan status sosial di TK ABA 1 Banjarmasin Kajian di Puskesmas Kota Banjarmasin Bulan September-Oktober 2014. Dentino, 2(1), 56-62.

Aged 10-12 Years: A Zero-Inflated Generalized Poisson Regression Model ARPPoach. Iran J Public Health, 45(3):.353-361.

Akbar, F.H., Pratiwi, R., \& Cendikiawan, R. (2017). Relationship between oral health status with knowledge, attitude, and behavior of elementary school children. Journal of International Dental and Medical Research,10(3): 921-926. Diakses dari http://www.jidmr.com.

Fahmi, Ismail. (2019). Southern Tapanuli Society Perception of Pulmonary TB Health and Diseases. Budapest International Research in Exact Sciences (BirEx) Journal, 95-105.

Gaur, S, Nayak, R. (2011). Under weight in low socioeconomic status Preschool children 
with severe early childhood caries. J Indian Soc Pedod Prev Dent, 29(4):305-9. doi:10.4103/0970-4388.8637

Halawany, H. S., Al Badr, A., Al Sadhan, S., Al Balkhi, M., Al-Maflehi, N., Abraham, N. B., ... \& Al Sherif, G. (2018). Effectiveness of oral health education intervention among female primary school children in Riyadh, Saudi Arabia. The Saudi dental journal, 30(3), 190-196.

Halim, M. P. (2011). Peran orangtua terhadap pemeliharaan kesehatan gigi dan mulut anak dan status kesehatan gigi dan mulut anak kelas II SD St. Yoseph 1 Medan (Tesis, Fakultas Kesehatan Masyarakat Unviersitas Sumatera Utara). Diakses dari bttp:// repository.usu.ac.id/bandle/ 123456789/33087

Handayani, H., \& Arifah, A. N. (2016). Hubungan pengetahuan, sikap dan tindakan kesehatan gigi dan mulut terhadap status kesehatan gigi siswa SMP/MTs Pondok Pesantren Putri Ummul Mukminin. Makassar Dental Journal, 5(2).

Haque, S.E., Rahman, M., Itsuko, K., Mutahara, M., Kayako, S., Tsutsumi, A., Islam, J., \& Mostof, M.G. (2016). Effect of a school-based oral health education in RPeventing untreated dental caries and increasing knowledge, attitude, and Practices among adolescents in Bangladesh. BMC Oral Health, 16:44 doi 10.1186/s12903-016-0202-3

Hsieh, HJ., Huang, ST., Tsai,CC., \& Hsiao, SY. (2012). Toothbrushing habits and risk indicators of severe early childhood caries among Aboriginal Taiwanese. Asia-Pacific Journal of Public Health, 20(10): 1 -10. Diakses dari doi: 10.1177/1010539511430721

Kidd, E., \& Sally, J. (2013). Dasar-dasar karies penyakit dan penanggulangannya. Alih Bahasa: Sumawinata Narlan dan Faruk Safrida. Jakarta : EGC.

Koch, G., Poulsen, S., Espelid, I., \& Haubek, D. (2017). Pediatric dentistry: a clinical arproach. John Wiley \& Sons.

Kyle, T., \& Carman, S. (2014). Pertumbuban dan perkembangan anak usia sekolah : dalam Keperawatan Pediatri. Jakarta; ECG.

Lely Suratri, M. A., Sintawati, F. X., \& Andayasari, L. (2016). Pengetahuan, sikap, dan perilaku orang tua tentang kesehatan gigi dan mulut pada anak usia Taman Kanak-kanak di RPovinsi Daerah Istimewa Yogyakarta dan Provinsi Banten Tahun 2014. Media Penelitian dan Pengembangan Kesehatan, 26(2), 119-126.

Maranhão, M.C., de Araújo, L.P., Vieira, K.A., \& Costa, L.S. (2013). Dental health knowledge and attitudes of primary school teachers toward dental health education in Maceió, Brazil. Brazilian Research in Pediatric Dentistry and Integrated Clinic, 14(2):115-128. Diakses dari doi: http://dx.doi.org/10.4034/PBOCI.2014.142.06.

Martins, M. T., Sardenberg, F., Vale, M. P., Paiva, S. M., \& Pordeus, I. A. (2015). Dental caries and social factors: impact on quality of life in Brazilian children. Brazilian oral research, 29(1).

Matondang, M. (2007). Status gizi dan pola makan pada anak taman kanak-kanak di Yayasan Muslimat RA Al-Ittihadiyah Medan Tahun 2007 (Skripsi Fakultas Kesehatan Masyarakat Universitas Sumatera Utara, Medan). Diakses dari http://repository.usu.ac.id/bitstream/handle/123456789/14668 /08E01511.pdf?sequence $=1$ \&isAllowed $=\mathrm{y}$

Papalia, D. E., Old, S.W., Feldman, R. D. (2008). Human Development (Psikologi Perkembangan). Ed.9 Cet.1. Jakarta: Kencana Prenada Media Group.

Petersen, P. E., Hunsrisakhun, J., Thearmontree, A., Pithpornchaiyakul, S., Hintao, J., Jürgensen, N., \& Ellwood, R. P. (2015). School-based intervention for improving the oral health of children in southern Thailand. Community Dent Health, 32(1), 44-50..

Pintauli, S., \& Hamada, T. (2015). Menuju gigi \& mulut sehat pencegahan dan pemeliharaan (Cetakan ke-3). Medan: USU Press.

Putri, R. M., Maemunah, N., \& Rahayu, W. (2017). Kaitan karies gigi dengan status gizi anak 
Pra sekolah. Care: Jurnal Ilmiah Ilmu Kesehatan, 5(1), 28-40.

Ramadhan, A., Cholil, C., \& Sukmana, B. I. (2016). Hubungan tingkat pengetahuan kesehatan gigi dan mulut terhadap angka karies gigi di smpn 1 marabahan. Dentino, 1(2), 66-69.

Rahmadhan AG (2010). Serba-serbi kesehatan gigi dan mulut. Jakarta: Bukune.

Rahman, E., \& Norfai, N. (2018). Hubungan perilaku kesehatan gigi anak kelas VII dengan status karies gigi Di SMP Negeri 3 Kota Banjarmasin. Jurnal Publikasi Kesehatan Masyarakat Indonesia, 5(1), 1-5.

Rahmawati I, Hendrartini J, Priyanto A (2011). Perilaku kesehatan gigi dan mulut pada anak sekolah dasar. Berita Kedokteran Masyarakat, 27(4),180-6.

Ramayanti, S., \& Purnakarya, I. (2013). Peran makanan terhadap kejadian karies gigi. Jurnal Kesehatan Masyarakat Andalas, 7(2), 89-93.

Romi Jain, Kunal C Oswal, Rajeev Chitguppi. Knowledge, attitude and practices of mothers toward their children's oral health: A questionnaire survey among subpopulation in Mumbai (India). doi: 10.4103/2348-3407.135073.

Sari, E. K., Ulfiana, E., \& Rachmawati, P. D. (2019). Pengaruh pendidikan kesehatan gosok gigi dengan metode permainan simulasi ular tangga terhadap perubahan pengetahuan, sikap, dan aplikasi tindakan gosok gigi anak usia sekolah di SD wilayah Paron Ngawi. Indonesian Journal of Community Health Nursing, 1(1).

Sirat, N. M., Senjaya, A. A., \& Wirata, I. N. (2016). Hubungan pola jajan kariogenik dengan karies pada siswa sekolah dasar di wilayah kerja Puskesmas III Denpasar Selatan, Bali 2016. Intisari Sains Medis, 8(3, 193-197 Diakses dari https://isainsmedis.id/index.php/ism/article/viewFile /146/162

Suciari, A., Arief, Y. S., \& Rachmawati, P. D. (2019). Peran orangtua dalam membimbing menyikat gigi dengan kejadian karies gigi anak prasekolah. Pediomaternal Nursing Journal, 3(2).

Ulfah, M., \& Al-Shodiq, M. (2005) Pendidikan dan pengasuban anak. Jakarta: PT. Gramedia Pustaka Utama.

Waryana. (2017). Promosi kesehatan penyuluhan dan pemberdayaan masyarakat (Edisi ke-1). Yogyakarta: Nuha Medika.

Worotitjan, I., Mintjelungan, C. N., \& Gunawan, P. (2013). Pengalaman karies gigi serta pola makan dan minum pada anak Sekolah Dasar di Desa Kiawa Kecamatan Kawangkoan Utara. $e-G I G I, 1(1)$. 